\title{
Geochmical evidence for recycling of the Paleo-Tethyan oceanic crust into the mantle source of syn-collisional mafic igneous rocks in China
}

\author{
WEI FANG*, LI-QUN DAI, YONG-FEI ZHENG
}

\author{
CAS Key Laboratory of Crust-Mantle Materials and \\ Environments, School of Earth and Space Sciences, \\ University of Science and Technology of China, Hefei \\ 230026, China
}

Crustal subduction generally develops from oceanic to continental slabs, with the disappearance of previously subducting paleo-oceanic crust in collisional orogens. However, it is difficult to identify the geochemical evidence of the subducted paleo-oceanic crust due to the modification of collisonal orogeny. This difficulty is overcome by a combined study of whole-rock major and trace elements, radiogenic Sr-Nd-Hf and stable O isotopes in syn-collisional mafic igneous igneous from the southeastern margin of the North China Block (NCB), which was underthrusted by the Paleo-Tethyan oceanic slab in the Late Paleozoic and then by the South China Block (SCB) in the Early Mesozoic. Zircon $\mathrm{U}-\mathrm{Pb}$ dating yields concordant ages of 247-244 Ma for magma emplacement, coeval with the initial collision between the NCB and SCB. The rocks generally exhibit OIBlike trace element distribution patterns, markedly different from arc-like patterns for common ones in continental margins. In addition, these rocks show intermediate $\left({ }^{87} \mathrm{Sr} /{ }^{86} \mathrm{Sr}\right)$ i ratios of 0.7057 to 0.7091 , weakly negative $\varepsilon_{\mathrm{Nd}}(\mathrm{t})$ values of -1.2 to -3.8 , and $\varepsilon_{\mathrm{Hf}}(\mathrm{t})$ values of -1.3 to -3.2 . These features indicate that their mantle source contains recycled crustal materials. The Triassic syn-magmatic zircons show variable $\mathrm{Hf}-\mathrm{O}$ isotope compositions, indicating that the crustal materials were composed of both altered oeanic basalt and terrigenous sediment. These mafic igneous rocks of Triassic have high $\mathrm{Fe} / \mathrm{Mn}$ and $\mathrm{Zn} / \mathrm{Fe}$ ratios, suggesting that their mantle source would be a kind of ultramafic pyroxenites. Thus, the pyroxenite was generated by metasomatic reaction of the mantle wedge peridotite with felsic melts derived from the subducting Paleo-Tethyan oceanic crust at postarc depths, where rutile in the subducting oceanic crust became broken down to cause the enrichment of $\mathrm{Nb}$ and $\mathrm{Ta}$ in the felsic melts. Such melts are diffferent from those produced by partial melting of the subducting oceanic crust at subarc depths, which are depleted in $\mathrm{Nb}$ and $\mathrm{Ta}$. Therefore, rutile is a critical mineral to the composition of subducition zone fluids. As such, the depth of slab subduction is a key to the stability of this mineral during the crust-mantle interaction in the PaleoTethyan oceanic subduciton channel. 